\section{Euricse}

European Research Institute

on Cooperative and Social Enterprises

\section{WORKING PAPER SERIES}

ISSN 2281-8235 Working Paper n. $72 \mid 14 \begin{aligned} & \text { Giacomo Degli Anto } \\ & \text { Gianluca Grimalda }\end{aligned}$

\title{
Groups and Trust: \\ Experimental Evidence on the Olson and Putnam Hypotheses
}

Please cite this paper as:

Degli Antoni, G. and Grimalda, G. (2014) "Groups and Trust:

Experimental Evidence on the Olson and Putnam Hypotheses", Euricse Working Papers, 72 | 14. 


\title{
Groups and Trust: \\ Experimental Evidence on the Olson and Putnam Hypotheses*
}

\author{
Giacomo Degli Antoni ${ }^{\mathrm{a}}$ and Gianluca Grimalda ${ }^{\mathrm{b}}$
}

\begin{abstract}
Mancur Olson and Robert Putnam provide two conflicting views on the effect of involvement with voluntary associations on their members. Putnam argues that associations instill in their members habits of cooperation, solidarity and public spiritedness. Olson emphasizes the tendency of groups to pursue private interests and lobby for preferential policies. We carry out the first field experiment involving a sample of members of different association types from different age groups and education levels, as well as a demographically comparable sample of non-members. This enables us to examine the differential patterns of behavior followed by members of Putnam-type and Olson-type associations. Coherently with both the Putnam's and Olson's view, we find that members of Putnam-type (Olson-type) associations display more (no more) generalized trust than non-members. However, when we examine trustworthy behavior we find the opposite pattern, with members of Olson-type (Putnam-type) associations more (no more) trustworthy than non-members. No relevant effect for the intensity of participation in associations emerges.
\end{abstract}

\section{Keywords}

Trust, Voluntary associations, Putnam, Olson, Field experiment

\section{JEL codes}

A13, D03, C93, Z13

\footnotetext{
*Acknowledgments: We would like to thank: Associazione Giocamico, Avis, A.vo.pro.ri.t, CGIL Parma, Comunità di Sant'Egidio, Corale Giuseppe Verdi, Coro Lirico Renata Tebaldi, Coro "Voci di Parma", Forum Solidarietà, Terra di Danza, and UIL Parma. Our thanks go to: Mariagrazia Ranzini and the staff of the library of the Department of Economics - University of Parma who have assisted us during fieldwork and Demoskopea s.r.l. for recruitment of participants in the research.

The paper benefited from comments by participants at the $53^{\text {rd }}$ Annual Conference of the Italian Economic Association (Matera, October 19-20, 2012), at the $8^{\text {th }}$ International Meeting on Experimental \& Behavioural Economics (Castellón de la Plana, 8-10 March 2012), at the Conference on "Socially Responsible Behaviour, Social Capital and Firm Performance" (Milan, 21-22 October 2011), and at seminars in Bologna and Parma. We would like to thank Giuseppe Vittucci Marzetti for precious comments and suggestions. Remaining errors are solely the responsibility of the authors.

The project was funded by the following grants: Bancaixa P1-1A2010-17, and P1-1B2010-17, Ministerio de Ciencia e Innovación de España (ECO2011-23634), Junta de Andalucía (P07-SEJ-03155), and by the Italian Ministry of University and Research under the national research project (PRIN) n. 20085BHY5T.

${ }^{a}$ Department of Law, University of Parma (Italy); and Econometica - Inter-University Center for Economic Ethics and Corporate Social Responsibility (Italy). E-mail:giacomo.degliantoni@unipr.it

${ }^{\mathrm{b}}$ Kiel Institute for the World Economy (Germany); Centre for Global Cooperation Research, University of Duisburg Essen (Germany); and University Jaume I of Castellón de la Plana (Spain). E-mail: gianluca.grimalda@ifw-kiel.de
} 


\section{Introduction}

The role of groups in shaping individuals preferences and modes of behavior has attracted the attention of many scholars in the social sciences. Two main theories on the relationship between groups and individuals are contrasted in contemporary investigations. The first is due to Robert Putnam. Drawing on Tocqueville's (1840) seminal analysis, Putnam posits that "associations instill in their members habits of cooperation, solidarity and public-spiritedness" (Putnam et al., 1993: 89-90). The second theory is due to Mancur Olson $(1965 ;$ 1982). Putnam's optimism on the beneficial role of associations is here replaced by a disenchanted view of the underlying reasons for the existence of associations. Olson emphasizes the tendency of groups to pursue private interests and lobby for preferential policies. Far from instilling public-spiritedness in the society, parochial and partisan interests prevail in the associations' objectives.

These two views are not necessarily irreconcilable. It has been argued that voluntary associations differ in characteristics and purposes. Some types of associations may operate in accordance with Putnam's theory, other with Olson's. In their seminal contribution, Knack and Keefer (1997) classify trade unions, political parties or groups, and professional associations as "Olson-type" associations, as these associations are "most representative of groups with redistributive goals" (Knack and Keefer, 1997: 1273). "Redistributive" here is synonym with rent-seeking behavior. The objective of these associations is mainly to redirect society's resources to the benefit of the association members. Education, arts, music or cultural activities; religious or church organizations; and youth work (e.g., scouts, guides, youth clubs, etc.) are defined as "Putnam-type" associations. They are "identified as those groups least likely to act as "distributional coalitions" but which involve social interactions that can build trust and cooperative habits" (Knack and Keefer, 1997: 1273).

The previous study, along with other contributions drawing on aggregate country-level data in order to study the effect of associational membership (see section 2 for a review), cannot take into account either the possibility that individuals are members of more than one type of association, or the intensity of their associational activity. Other studies, reviewed in section 2, analyze the effect of associational membership using individual-level surveys (Stolle and Rochon, 1998; Stolle, 1998; Wollebaek and Selle, 2002). Although these contributions are better able to investigate the micro-mechanisms of the relationship between prosociality and membership in voluntary associations, the possibility of confounding effects and misreporting that is intrinsic in survey questions hamper their conclusions (e.g. Bertrand and Mullainathan, 2001; Glaeser et al., 2000; Anderson et al., 2004). Moreover, the use of survey questions on trust has raised much criticism. As Glaeser et al. (2000: 800) put it, "While these survey questions are interesting, they are also vague, abstract, and hard to interpret".

In this paper we revert to an experimental analysis to examine the differential patterns of behavior followed by members of Putnam-type and Olson-type associations. We carry out the first field experiment involving a sample of members of different association types from different age groups and education levels, as well as a demographically comparable sample of non-members. We investigate the level of generalized trust (towards people from the general population) and particularized trust (trust towards fellow members) ${ }^{1}$, of members of Putnam-type, Olson-type and other types of association within a Trust Game (Berg et al., 1994).

\footnotetext{
${ }^{1}$ Generalized trust may be interpreted as a general predisposition toward other people, especially people whom one does not know (Uslaner, 2002) and may be defined as "a trust that goes beyond the boundaries of kinship and friendship and even beyond the boundaries of acquaintance" (Stolle and Rochon, 1998: 48). It differs from the notion of particularized trust which consists in
} 
First of all, our analysis aims at testing four main hypotheses inspired by the Putnam's and Olson's approaches that we will call PUTNAM HYPOTHESES ( $A$ and $B$ ) and OLSON HYPOTESES ( $A$ and $B)$ :

1) PUTNAM HYPOTHESIS A: Members of Putnam-type associations display more trust towards the general public (i.e. generalized trust) than non-members;

2) PUTNAM HYPOTHESIS B: The level of trust toward their own association members is higher than the level of trust towards the general public for members of Putnam-type associations; that is, particularized trust is higher than generalized trust;

3) OLSON HYPOTHESIS A: Members of Olson-type associations do not show higher levels of generalized trust than non-members;

4) OLSON HYPOTHESIS B: Members of Olson-type associations display more particularized than generalized trust.

The two "B Hypotheses", i.e. that interaction within associations are characterized by higher level of trust than interactions between association members and strangers, are based on the concept of direct and indirect reciprocity (Fehr and Gächter, 2000; Seinen and Schram, 2006; Engelmann and Fischbacher, 2009). Social networks generated through the association trigger mechanisms based on reciprocity, reputation, monitoring and sanctioning that increase cooperation among members of the same group (Putnam et al., 1993; Putnam, 2000; Paxton, 2007). Indeed, we should observe members of associations to trust fellow members more than people from the general public regardless of association types.

However, Putnam and other followers of the Tocquevillian tradition argue that participation in associations also fosters pro-social attitudes in interactions with generalised others in the society at large, that is, outside the association. This may be in part explained by the very fact that associations increase the density and the overlap of social networks, as this activates the mechanisms based on reciprocity, reputation, monitoring and sanctioning mentioned above. Nevertheless, in large part, this is also based on the conjecture that associational membership will work towards increasing trust in, and co-operation with, absolute strangers (Putnam et al., 1993; Brehm and Rahn, 1997; Stolle and Rochon, 1998; Putnam, 2000; Wollebaek and Selle, 2002). From this approach we derive our PUTNAM HYPOTHESIS A.

Conversely, Olson's view $(1965 ; 1982)$ hinges upon the role of associations in pursuing private interests of members and in relegating the general public interest to a minor role. From this perspective, we expect associations not to affect positively generalized trust (OLSON HYPOTHESIS A).

Secondly, not only does the Trust Game allow us to analyze Putnam-type and Olson-type members' patterns of trusting behavior, but also it enables us to study their trustworthiness. ${ }^{2}$ Our study is the first to tackle the issue of trustworthiness in relation to different types of association.

relying only on people who belong to one's own "moral community" and share the same characteristics (Uslaner, 2002). Berggren and Jordahl (2006: 143) distinguish between particularized trust and generalized trust where "the former entails trusting people you know or know something about; the latter trusting most (but not all) people you do not know or know anything about". In this perspective, the notion of knowledge-based trust (Yamigishi and Yamigishi, 1994) clarifies that particularized trust is strictly related to the available information.

${ }^{2}$ We are aware that different motivational drivers may lead subjects' decisions in Trust Games (e.g. Becchetti and Degli Antoni, 2010). In particular, subjects may be motivated by other regarding preferences (Cox, 2004), altruistic or inequality-averse preferences (Fehr and Schmidt, 1999), social-welfare preferences (Charness and Rabin, 2002), warm glow (Andreoni, 1989; 1990) and trust (only on the part of the first mover) or reciprocity (only on the part of the second mover). We are not able, neither is it an aim of our analysis, to disentangle among the different motivations behind subjects' decision in our Trust Game. We simply assume that a higher amount sent by the Sender and a higher share returned by the Receiver are representative of a greater propensity to cooperate. In what follows, we generically refer to trust and trustworthiness when talking about Senders' and Receivers' behavior. 
Finally, we also examine whether increasing one's involvement with associations affects the behavior of members of different types of associations in our Trust Game. For this purpose we analyze the impact of the number of associations that an individual has joined and the number of hours that individuals report as spending in associational meetings and activities every week.

We investigate the previous issues by randomizing our sample into an in-group and an out-group treatment. In the in-group treatment association members are paired with people from their own association. In the out-group treatment they are paired with people from the general population. Behavior in the in-group and out-group treatments gives us a measure of particularized and generalized trust, respectively. The comparison with the behavior of people from the general population also enables us to contrast generalized trust by members and non-members.

We follow Knack and Keefer's (1997) classification of Olson-type and Putnam-type associations. We involve in our experiment members of trade unions and cultural associations (see section 3). These are representative of the former and latter group, respectively. We also examine the behavior of members of social welfare and health services associations, which we call "Residual" associations, as they are not included in either category in the original Knack and Keefer's (1997) classification.

Both the PUTNAM HYPOTHESIS $A$ and the OLSON HYPOTHESIS $A$ are confirmed by our experimental evidence. Members of Putnam-type associations trust people from the general population more than nonmembers (PUTNAM HYPOTHESIS A). Members of Olson-type associations treat people from the general population in the same way as non-members (OLSON HYPOTHESIS A). With respect to the "B hypotheses", no in-group effect emerges with respect to members of Putnam-type associations, i.e. they trust fellow members as they trust people from the general population. That is, PUTNAM HYPOTHESIS $B$ is not supported by our evidence. Conversely, the level of particularized trust of members of Olson-type associations towards fellow members is higher than generalized trust towards general others. This supports OLSON HYPOTHESIS B.

As far as Residual associations are concerned, their members show patterns of trusting behavior in our experiments that are alike members of Putnam-type associations' both toward generalized others and fellow members.

The analysis of receivers' decisions brings about a surprising result. In this case members of Olson-type associations return significantly more than people from the general public, both when they are matched with fellow Olson-type members, and when they interact with people from the general public. The same pattern occurs for Residual association members who also show in-group favoritism, i.e. they return more to their fellow members than to people from the general public. By contrast, Putnam-type association members are no more trustworthy than people from the general public, either in the in-group, or in the out-group treatment.

Finally, we find a negative effect of the number of hours spent volunteering in the associations on trusting behavior of members of Olson-type association when paired with people from the general public. No other effect of the intensity of participation emerges.

The outline of the paper is as follows. Section 2 reviews the related literature on the relationship between association membership and trust. Section 3 summarizes the experimental design and describes our sample. Section 4 presents descriptive statistics and the econometric analysis. Section 5 concludes. 


\section{Related literature on the relationship between association membership and trust}

In their cross-country survey analysis, Knack and Keefer (1997) find a negative, albeit insignificant, effect of Putnam-type associations on generalized trust and a positive effect of Olson-type associations. They also find that Olson-type (Putnam-type) associations are positively (negatively) associated with an index of civic attitude. Knack (2003) uses larger country coverage than Knack and Keefer (1997) and finds a positive effect of Putnam-type associations on generalized trust, while the effect of Olson-type associations is insignificant ${ }^{3}$. Other studies have used individual-level data to analyze the relationship between generalized trust and association membership distinguishing between different types of associations. Stolle and Rochon (1998) show that in $76.5 \%$ of the cultural associations they survey ${ }^{4}$, which are Putnam-type in character, members score significantly higher than non-members in an index based on questions on trust in others and on the frequency of interactions with neighbors, e.g. to borrow money or other items. They also find that members of as few as $30 \%$ of Olson-type associations ${ }^{5}$ display higher levels of the previous index than non-members. Finally, as far as Residual associations are concerned, Stolle and Rochon (1998) find that $52.6 \%$ of Community groups' members and $57.9 \%$ of Private interest groups' members show higher levels of the index than non-members ${ }^{6}$. Wollebaek and Selle (2002) find that the percentage of respondents who say that "Most people can be trusted" is higher among members of Putnam-type associations (culture and recreational associations - 68\% - and religious - 73\%) and of Olson-type associations (parties and unions 77\%) than among non-affiliated (54\%). However, the association type is not significant in explaining the presence of trustful members once multiple affiliations are considered as a control variable in a multivariate regression analysis. Stolle (1998) presents descriptive evidence detailing a higher level of generalized trust, measured through a set of trust questions, for members of sport associations and church choirs (Putnam-type association type) in comparison with customers of a commercial gymnasium. The latter are involved in activities similar to those of association members, but know each other less and spend less time together after joining the activity than association members.

Our study is innovative with respect to the existing literature because of its experimental character. This allows us to investigate the relationship between association membership and trust by using an experimental measure of trust and by taking into account both multiple membership and the effect of intensity of participation.

\footnotetext{
${ }^{3}$ Knack (2003) adopts the same classification used by Knack and Keefer (1997) with regard to Olson-type associations, while religious or church organizations are dropped from the Putnam-type associations where sport or recreation associations and local community action on issues like poverty, employment, housing, racial equality are included.

${ }^{4}$ According to Stolle and Rochon's classification, cultural associations include: associations for the preservation of traditional regional, national, or ethnic culture; church groups; literary, music, and art society. Members of this association type appear also to be characterized be high scores in indexes of Political Action, Political Trust and Optimism, Tolerance and Free-ridership (Stolle and Rochon, 1998).

${ }^{5}$ They consider economic associations that include unions, employers' associations, professional associations, agricultural associations, consumer groups, cooperatives, shareholders' organizations. Members of this association type appear also to be characterized be high values of indices of Political Action and Political Trust.

${ }^{6}$ Community groups include: local actions groups, resident's associations, service and welfare organizations, health care groups, parents' associations, voluntary defense associations. Members of this association type seem to be also characterized be high values of indices of Political Action, Political Trust and Optimism, Tolerance and Free-ridership. Private interests groups include: sport, outdoor, youth, hobby, and auto. Members of this association type appear also to be characterized be high values of indices of Political Action, Political Trust and Optimism, Tolerance and Free-ridership.
} 


\section{Experimental design and sample}

In our Trust Game experiment both senders and receivers are endowed with 25 euro $(€)$. The sender is the first player to move. She has to decide how much of her initial endowment to send to the receiver, in multiples of $5 €$. Therefore six transfer levels are possible $(0,5,10,15,20$ or $25 €)$. The amount sent is doubled by the experimenter. The receiver has to decide how much of the amount in her possession after the sender's choice - i.e. the initial $25 €$, plus the amount sent by the sender and doubled by the experimenter - to send back to the first mover. We adopted the strategy method, so receivers had to indicate the amount they would like to return for each of the possible six options available to the sender.

The experiment was conducted between May and October 2011 at the University of Parma library. Recruited subjects were randomly assigned to two different groups prior to the session, and were summoned to two meeting points of the university. We took care that the two groups did not meet each other while they were conducted to two different rooms of the library. All sessions were run in parallel in the two rooms by the two researchers, following an identical script.

All subjects took two decisions, the first one as senders and the second one as receivers. When they took the first decision as senders, subjects did not know that they would have taken the second decision as receivers. Subjects present in one room were told that they would have been matched anonymously with another subject present in the other room. Pairs were changed after the first decision and no feedback was given at the end of each choice, so we consider the two choices as independent. Subjects were paid only for one decision, each of them having $50 \%$ probability of being drawn.

After the two experimental decisions, we elicited subjects' beliefs over sender and receiver behavior and we administered the post-experiment questionnaire. Payments were distributed in cash at the end of the session.

Sessions lasted on average 75 minutes. The average payoff was 31.7 euro (std. dev. 11.99).

374 subjects took part in the experiment. 263 subjects were formally affiliated to a voluntary association, and attended meetings for at least one hour per month ("members" henceforth). They were recruited by the experimenters in ten different associations operating in the Province of Parma. Four were cultural associations (one ethnic and traditional dance association and three choirs). Following Knack and Keefer (1997), we classify them as Putnam-type associations. Two of the associations were trade unions, which we classify as Olson-type associations. Four associations were social welfare and health services associations (an association assisting hospitalized children, an association for medical research on cancer, the Italian association for blood donation and an association dedicated to charity and evangelization), which we classify as Residual associations.

111 participants were not formally affiliated at the time the research was conducted ("non-members" henceforth). 77 non-members had never been members in the past, while 34 non-members had been members of associations in the past but not at the moment of the experiment (dropouts). Since we never find differences between these two latter groups (see also Degli Antoni and Grimalda, 2013) we treat them as a single category in the rest of the analysis. Non-members were recruited by Demoskopea, one of the most well-known opinion polls and market research agency in Italy ${ }^{7}$. Contact with potential subjects was carried out in person by experimenters through announcements at association meetings and over the phone by Demoskopea staff. In spite of the different type of contact we requested that all announcements with potential subjects were made following an identical recruitment script. In this way, potential subjects were given exactly the same information prior to coming to the research sessions.

\footnotetext{
${ }^{7}$ Four non-members were recruited by the experimenters to make up for no-shows.
} 


\subsection{The in-group treatment sample}

109 members took part in the in-group treatment. Table 1 reports the number of subjects from each association type.

Table 1 - Number of subjects per association type "in-group"

\begin{tabular}{lc}
\hline & In-group \\
\hline Putnam-type & 38 \\
Olson-type & 30 \\
Residual & 41 \\
\hline
\end{tabular}

In the in-group treatment subjects were informed that they were paired with a member of the same association from which they had been contacted by the experimenters and that this subject was taking part to the session in the other room. The instructions read: "The person with whom you will be paired is a member of the Association ' $X$ ' of which you are also a member, and is resident in Parma, or its province, or in neighbouring provinces. He was asked to take part in the research in a similar way to how you have been contacted" (' $X$ ' was the name of the association).

\subsection{The out-group treatment sample}

265 subjects took part in the out-group treatment. They included all the 111 non-members and the remaining 154 members. Members were recruited by the experimenters in the same ten associations mentioned above except for 11 members who were recruited by Demoskopea ${ }^{8}$.

We operate a finer distinction in the out-group treatment than in the in-group with respect to assignment to association types. While in the in-group treatment we only take into account the association where subjects had been recruited, we consider all associations of which a person is a member for our analyses relative of the out-group treatment. This yields seven mutually exclusive categories: (1) People belonging to one type of association only - namely, people belonging to just Putnam-type associations (which we call "Putnam-type only" henceforth); or (2) just Olson-type associations ("Olson-type only" henceforth); or (3) just Residual associations ("Residual only" henceforth) - namely, people belonging to two types of associations; or (4) people belonging to Putnam-type and Olson-type associations ("Putnam-type \& Olsontype" henceforth); or (5) to Putnam-type and Residual-type associations ("Putnam-type \& Residual" henceforth); or (6) Olson-type and Residual-type associations (“Olson-type \& Residual” henceforth); finally, (7) people belonging to all three types of association ("All types" henceforth).

The reason why we operate this finer distinction in the out-group treatment and not in the in-group is that in the latter treatment we only measure particularized trust, which strictly depends on the association where subjects have been recruited. In fact, members recruited from an association in the in-group

\footnotetext{
${ }^{8}$ We had asked Demoskopea to recruit only non-members or dropouts. However, during the recruitment interview with Demoskopea, 11 subjects answered negatively to the screening question on whether a person is part of an association but they reported in the post-experiment questionnaire that they actually were association members. We suppose that this may be due to subjects' absent-mindedness when answering the recruitment interview, so we have decided to keep these 11 subjects in the sample as members. They have been classified as belonging to "other associations"
} 
treatment are paired with other members belonging to that same association. Conversely, generalized trust measured in the out-group treatment may be affected not only by membership in the association from where subjects were recruited, but also by the other different types of association where subjects were active.

Table 2 summarizes the size of association membership per type of association in the out-group treatment.

Table 2 - Number of subjects per association type "out-group"

\begin{tabular}{lc}
\hline & Out-group \\
\hline Non-members & 111 \\
Putnam-type Only & 29 \\
Olson-type Only & 30 \\
Residual Only & 34 \\
Putnam \& Olson-type & 12 \\
Putnam \& Residual-type & 25 \\
Olson \& Residual-type & 12 \\
All Types & 11 \\
\hline
\end{tabular}

The script in the out-group treatment read that more than a thousand people of different age and socioeconomic conditions residents in the province of Parma and surrounding provinces had been contacted. Sessions in the out-group treatment comprised members coming from many different types of association, so most of the people part of this group would, with high probability, not be acquainted with each other. In the post-experiment questionnaire we asked subjects to state whether they thought they knew personally persons present in the other room. Around 7\% (41\%) of members participating in the out-group (in-group) treatment answered positively to such question. This difference is statistically significant $(P<0.001$; MannWhitney test).

\subsection{Sample properties}

We test for the demographic comparability between the various member groups and non-member groups across the two treatments with Chi square and Wilcoxon non-parametric tests. We find two significant differences (Table 3). They concern the number of subjects who attained high-school diploma as their highest educational achievement among members of Residual associations in the two different treatments, and the satisfaction with personal financial situation as declared by the respondent between members and non-members. The latter is used as a proxy for the subject's economic condition. The econometric analysis will control for these differences. 
Table 3 - Balancing properties per experimental condition and type of association

\begin{tabular}{|c|c|c|c|c|c|}
\hline & Age & Female & Bachelor's_degree & Secondary_school & $\begin{array}{c}\text { Income } \\
\text { satisfaction }\end{array}$ \\
\hline $\begin{array}{l}\mathrm{H}_{0}: \text { Non-member }= \\
\text { Members }\end{array}$ & $\begin{array}{l}1.522 \\
(0.128)\end{array}$ & $\begin{array}{l}0.0278 \\
(0.868)\end{array}$ & $\begin{array}{l}0.1840 \\
(0.668)\end{array}$ & $\begin{array}{l}1.4063 \\
(0.236)\end{array}$ & $\begin{array}{l}-2.941 \\
(0.0033)\end{array}$ \\
\hline $\begin{array}{l}\mathrm{H}_{0} \text { : Members of } \\
\text { Putnam-type } \\
\text { associations (in- } \\
\text { group) = Members of } \\
\text { Putnam-type } \\
\text { associations (out- } \\
\text { group) }\end{array}$ & $\begin{array}{l}-1.008 \\
(0.313)\end{array}$ & $\begin{array}{l}0.1757 \\
(0.675)\end{array}$ & $\begin{array}{l}1.3271 \\
(0.249)\end{array}$ & $\begin{array}{l}0.2219 \\
(0.638)\end{array}$ & $\begin{array}{l}0.0341 \\
(0.854)\end{array}$ \\
\hline $\begin{array}{l}\mathrm{H}_{0} \text { : Members of } \\
\text { Olson-type } \\
\text { associations (in- } \\
\text { group) = Members of } \\
\text { Olson-type } \\
\text { associations (out- } \\
\text { group) }\end{array}$ & $\begin{array}{l}-0.243 \\
(0.8081)\end{array}$ & $\begin{array}{l}2.0142 \\
(0.156)\end{array}$ & $\begin{array}{l}0.7629 \\
(0.382)\end{array}$ & $\begin{array}{l}2.5124 \\
(0.113)\end{array}$ & $\begin{array}{l}0.0770 \\
(0.781)\end{array}$ \\
\hline $\begin{array}{l}\mathrm{H}_{0} \text { : Members of } \\
\text { Residual associations } \\
\text { (in-group) = Members } \\
\text { of Residual } \\
\text { associations (out- } \\
\text { group) }\end{array}$ & $\begin{array}{c}1.683 \\
(0.0924)\end{array}$ & $\begin{array}{l}0.0049 \\
(0.944)\end{array}$ & $\begin{array}{l}1.2018 \\
(0.273)\end{array}$ & $\begin{array}{l}4.3787 \\
(0.036)\end{array}$ & $\begin{array}{c}0.0308 \\
(0.8861)\end{array}$ \\
\hline
\end{tabular}

\section{Empirical evidence}

\subsection{Descriptive statistics}

Drawing on the same dataset used in this paper, Degli Antoni and Grimalda (2013) show that members send and return significantly more than non-members. The novelty of the present paper is to show that significant differences do emerge in this general pattern when we distinguish between Putnam-type, Olsontype and Residual associations. Tables 4 and 5 summarize descriptive statistics across treatment and per association type for the amount sent and the return rate respectively.

As far as the amount sent is considered (Table 4), descriptive statistics seem to reveal two main patterns, which are also confirmed by non-parametric tests:

1) Members of associations contribute significantly more than non-members in the out-group treatment in all cases but two. In both cases Olson-type associations are involved. Such are members of both Putnam-type and Olson-type associations (Mann-Whitney $p=0.3266$ ) and members of both Olson-type and Residual associations (Mann-Whitney $p=0.8546)^{9}$.

\footnotetext{
${ }^{9}$ Differences between non-members and members of other combinations of associations as reported in Table 4 are always significant at the $5 \%$ level except when we consider members of Putnam-type, Olson-type and Residual where the level of significance is at the $10 \%$ level. The tests are available upon request.
} 
2) No difference emerges between the in-group and the out-group treatment in the amount sent by members of Putnam-type (Mann-Whitney $p=0.5741$ ), Olson-type (Mann-Whitney $p=0.5147$ ) and Residual (Mann-Whitney $\mathrm{p}=0.9125$ ) associations. In order to analyze the existence of in-group/outgroup effects we compare the difference in amounts sent for in-group members and out-group members who belong to strictly one association type.

Table 4 - Amount sent across treatment and association membership

\begin{tabular}{|c|c|c|c|c|}
\hline & \multicolumn{2}{|c|}{ Out-group } & \multicolumn{2}{|c|}{ In-group } \\
\hline & Median & $\begin{array}{c}\text { Mean } \\
\text { (Std.Dev) }\end{array}$ & Median & $\begin{array}{c}\text { Mean } \\
\text { (Std.Dev) }\end{array}$ \\
\hline Non-members & 10 & $\begin{array}{l}10.496 \\
(6.973)\end{array}$ & & \\
\hline Members of Putnam-type only & 15 & $\begin{array}{l}15.172 \\
(5.587)\end{array}$ & 15 & $\begin{array}{l}14.342 \\
(5.947)\end{array}$ \\
\hline Members of Olson-type only & 15 & $\begin{array}{c}14.5 \\
(6.345)\end{array}$ & 15 & $\begin{array}{l}15.833 \\
(6.833)\end{array}$ \\
\hline Members of Residual only & 15 & $\begin{array}{l}15.441 \\
(6.783)\end{array}$ & 15 & $\begin{array}{l}15.610 \\
(5.612)\end{array}$ \\
\hline Members of Putnam-type and Olson-type & 12.5 & $\begin{array}{l}12.917 \\
(7.821)\end{array}$ & & \\
\hline Members of Putnam-type and Residual & 15 & $\begin{array}{c}14.8 \\
(6.994)\end{array}$ & & \\
\hline Members of Olson-type and Residual & 10 & $\begin{array}{c}11.25 \\
(6.440)\end{array}$ & & \\
\hline $\begin{array}{l}\text { Members of Putnam-type, Olson-type and } \\
\text { Residual (All types) }\end{array}$ & 15 & $\begin{array}{l}14.091 \\
(5.394)\end{array}$ & & \\
\hline $\begin{array}{l}\text { Members of at least one Putnam-type } \\
\text { association }\end{array}$ & 15 & $\begin{array}{l}14.545 \\
(6.344)\end{array}$ & & \\
\hline $\begin{array}{l}\text { Members of at least one Olson-type } \\
\text { association }\end{array}$ & 15 & $\begin{array}{l}13.538 \\
(6.479)\end{array}$ & & \\
\hline $\begin{array}{l}\text { Members of at least one Residual } \\
\text { association }\end{array}$ & 15 & $\begin{array}{l}14.451 \\
(6.667)\end{array}$ & & \\
\hline
\end{tabular}

Members of at least one $X$ association identifies subjects who are members of at least one association of type $X$. For instance, members of at least one Olson-type association includes members of: Olson-type only; Putnam-type and Olson-type; Olson-type and Residual; All types.

As far as the amount returned is considered (Table 5 - we consider the average return rate on the six possible transfer rates available to the receiver in our Trust Game), descriptive statistics and nonparametric tests reveal that:

1. Members of all the different types of associations seem to return significantly more than nonmembers (this is also clearly shown in Figure 1). The statistical significance is stronger for members of Olson-type only associations (Mann-Whitney $p=0.0025$ ) and members of Residual-type only (Mann-Whitney $p=0.0054$ ) than for members of Putnam-type only (Mann-Whitney $p=0.0256$ ) associations. When we consider multiple associations versus non-membership, statistically significant differences emerge with respect to members of Putnam-type and Residual (MannWhitney $p=0.0199$ ), at least one Putnam-type association (Mann-Whitney $p=0.0029$ ), at least one 
Olson-type association (Mann-Whitney $\mathrm{p}=0.0016$ ) and at least one Residual association (MannWhitney $p=0.0006$ ).

2. No difference emerges between the in-group and the out-group treatment in the amount returned by members of Putnam-type (Mann-Whitney $p=0.5145$ ), Olson-type (Mann-Whitney $p=0.7956$ ) and Residual (Mann-Whitney $\mathrm{p}=0.1115$ ) associations.

Table 5 - Return rate across treatment and association membership (average on six possible transfer rates)*

\begin{tabular}{|c|c|c|c|c|}
\hline & \multicolumn{2}{|c|}{ Out-group } & \multicolumn{2}{|c|}{ In-group } \\
\hline & Median & $\begin{array}{c}\text { Mean } \\
\text { (Std.Dev) }\end{array}$ & Median & $\begin{array}{c}\text { Mean } \\
\text { (Std.Dev) }\end{array}$ \\
\hline Non-members & 0.219 & $\begin{array}{c}0.243 \\
(0.180)\end{array}$ & & \\
\hline Members of Putnam-type only & 0.282 & $\begin{array}{c}0.301 \\
(0.146)\end{array}$ & 0.285 & $\begin{array}{c}0.277 \\
(0.106)\end{array}$ \\
\hline Members of Olson-type only & 0.295 & $\begin{array}{c}0.349 \\
(0.185)\end{array}$ & 0.319 & $\begin{array}{c}0.331 \\
(0.169)\end{array}$ \\
\hline Members of Residual only & 0.318 & $\begin{array}{c}0.313 \\
(0.151)\end{array}$ & 0.331 & $\begin{array}{c}0.398 \\
(0.207)\end{array}$ \\
\hline Members of Putnam-type and Olson-type & 0.261 & $\begin{array}{c}0.282 \\
(0.133)\end{array}$ & & \\
\hline Members of Putnam-type and Residual & 0.300 & $\begin{array}{c}0.303 \\
(0.119)\end{array}$ & & \\
\hline Members of Olson-type and Residual & 0.299 & $\begin{array}{c}0.278 \\
(0.082)\end{array}$ & & \\
\hline $\begin{array}{l}\text { Members of Putnam-type, Olson-type and } \\
\text { Residual (All types) }\end{array}$ & 0.282 & $\begin{array}{c}0.339 \\
(0.229)\end{array}$ & & \\
\hline $\begin{array}{l}\text { Members of at least one Putnam-type } \\
\text { association }\end{array}$ & 0.282 & $\begin{array}{c}0.304 \\
(0.149)\end{array}$ & & \\
\hline $\begin{array}{l}\text { Members of at least one Olson-type } \\
\text { association }\end{array}$ & 0.295 & $\begin{array}{c}0.322 \\
(0.170)\end{array}$ & & \\
\hline $\begin{array}{l}\text { Members of at least one Residual } \\
\text { association }\end{array}$ & 0.298 & $\begin{array}{c}0.308 \\
(0.146)\end{array}$ & & \\
\hline
\end{tabular}


Figure 1 - Return share across treatment and association membership distinguishing between members of different types of associations and non-members

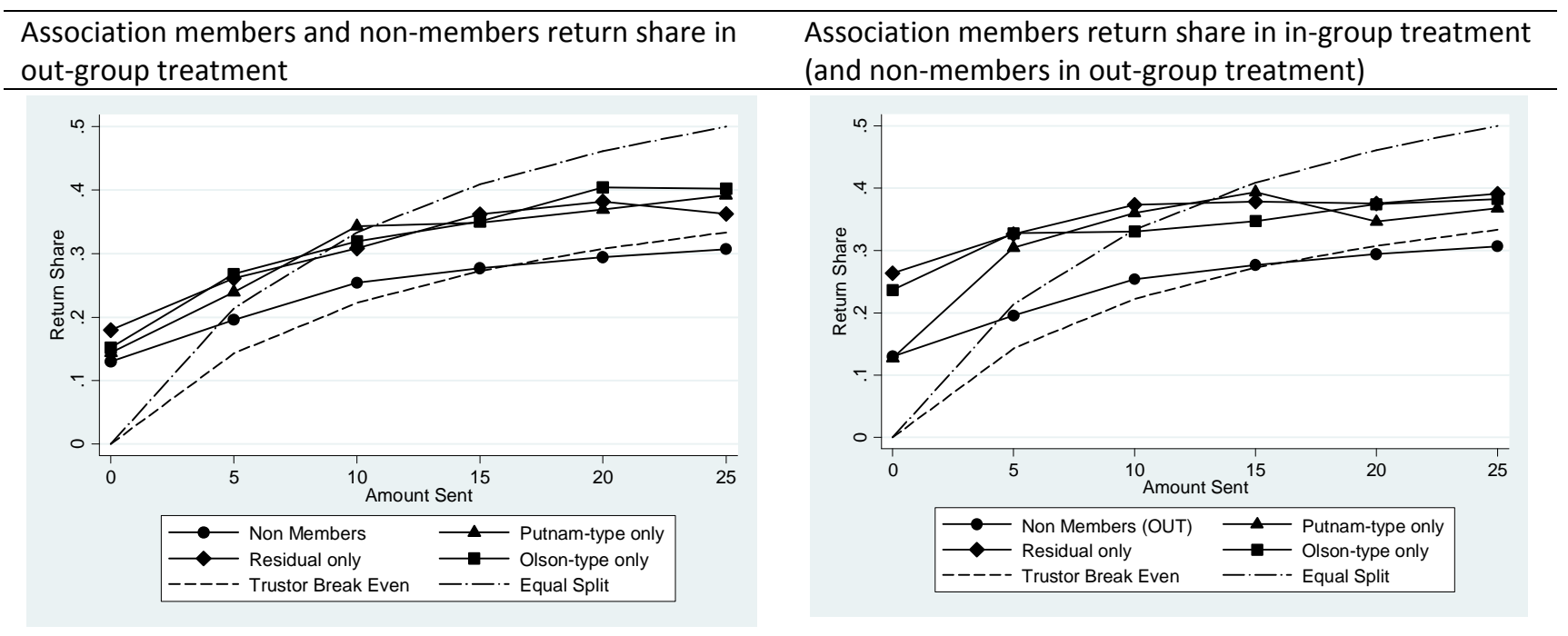

\subsection{Econometric analysis}

In order to investigate the differences in choices by senders in consideration of their associational condition, we perform Ordered Logit estimates on the amount sent, which could vary between $0 €$ and $25 €$ in multiples of $5 €$. We define Amount sent* a sender's unobservable willingness to trust others, modelled as a function of a vector of independent variables. The mapping between Amount sent ${ }^{*}$ and the variable we observe in the experiment, Amount sent, is then given by:

$$
\begin{aligned}
& \text { Amount sent }_{i}{ }^{*}=\alpha+G_{i}^{\prime} b+X_{i}^{\prime} \delta+\varepsilon_{i} \\
& \text { Amount sent }_{i}=k \text { if } m_{k-1}<\text { Amount sent }{ }_{i}{ }^{*} \leq m_{k}, k=0, \ldots, K
\end{aligned}
$$

$\alpha$ is a constant term. The index $i$ denotes the individual. $G_{i}$ is a vector which includes dummy variables identifying the types of association to which subjects belong. Variables included in vector $G_{i}$ change across different specifications and are described in detail below. $X_{i}$ is a vector including a wide array of control variables. It includes socio-demographic characteristics, such as age, sex, education, occupational condition, satisfaction with health and income, the propensity to take financial risk and controls connected with the experimental conditions, namely, a dummy identifying the two experimenters who led the sessions in two different rooms and the number of errors in the comprehension questions. Finally, the vector $X_{i}$ also includes a dummy variable identifying dropouts, which is never different from other nonmembers. The description of these variables is reported in Appendix A. $B$ and $\delta$ are vectors of parameters of interest, and $\varepsilon_{i}$ is the error term, assumed to be distributed according to a standardised Logistic distribution $\mathcal{E}_{i} \sim \operatorname{Logistic}(0,1)$. The index $k$ represents the discrete possible amounts sent and $K$ the total number of categories. In our experiment, $K=6 . m_{k}$ are the (unobservable) cutoff points in the domain of Amount sent ${ }_{i}{ }^{*}$ at which the individual desires to switch to a higher Amount sent ${ }_{i}$. We make the usual normalisation, $m_{-1}=-\infty, m_{0}=0$, and $m_{k}=+\infty$.

In order to investigate the effect of associational membership on receivers' decision, we fit a Tobit model where the dependent variable is the return rate. The receiver could return any amount ranging from zero up to a maximum given by the sum of the receiver's initial endowment $(25 €)$ and twice the amount sent to her by the sender. Returns were allowed up to the first decimal digit. We normalize this variable to the 
$[0,1]$ interval by dividing it by the maximum possible amount that receivers may send back. We call this variable Return rate.

The econometric analysis of the Return rate is based on the following Tobit model with random effects:

Return rate $_{i}^{*}=\gamma_{0}+\gamma_{1}$ Amount sent $_{j}+\gamma_{2}\left(\text { Amount sent }_{j}\right)^{2}+G^{\prime}{ }_{i} b+X_{i}^{\prime} \delta+\theta_{i}+\vartheta_{a i}$

Return rate $_{i}= \begin{cases}1 & \text { if } \text { Return rate }_{i}{ }^{*} \geq 1 \\ \text { Return rate }_{i}^{*} & \text { if } 0<\text { Return rate }_{i}^{*}<1 \\ 0 & \text { if } \text { Return rate }_{i}{ }^{*} \leq 0\end{cases}$

Eq. (3) describes an individual's latent propensity to send back to the sender a share of the money in her

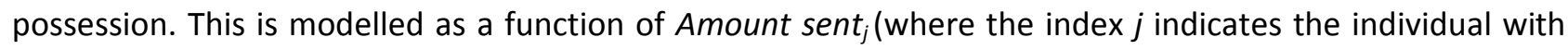
which individual $i$ is paired). $G_{i}$ and $X_{i}$ includes the same variables of interest and control variables used in the Ordered Logit estimates. $\beta$ and $\delta$ denote vectors of parameters. Finally, $\theta_{i}$ and $\vartheta_{a i}$ are an individualspecific and an idiosyncratic error term, respectively. The quadratic form in Amount sent $t_{j}$ is added to capture possible non-linearities in the way receivers respond to the amount received (Bellemare and Kröger, 2007). Eq. (4) presents the censoring rules that force receiver with either extremely high or extremely low propensity to send back money to return a rate of one or zero, respectively, with positive probability.

First, we examine whether members of different types of associations showed different patterns of behavior in relation to non-members in the in-group treatment (Table 6, column 1). Amounts sent by members are significantly higher than the amounts sent by non-members when members interact with fellow members for any of the three association types (Putnam-type_Ing; Olson-type_Ing and Residual_Ing; $p<0.01$ in all three cases - Table 6 , column 1). When association members interact with people from the general population in the out-group treatment, we find that people who are member of only Olson-type associations (Olson-type_Only_Out) do not show any significant difference in their amount sent in comparison with non-members $(p=0.116$ - Table 6 , column 1$)$. On the contrary, both members of only Putnam-type associations (Putnam-type_Only_Out) and only Residual associations (Residual_Only_Out) do show significantly higher amount sent than non-members ( $p=0.020$ for Putnam-type associations; $p=0.010$ for Residual associations - Table 6, column 1). Interestingly enough, people who are members of both Putnam-type and Residual associations (Putnam-type_\&_Residual_Out) send significantly higher amounts than non-members $(p=0.011)$, while in cases in which individuals are involved with two associations and one of them is Olson-type (Putnam-type_\&_Olson-type_out, Olson-type_\&_Residual_out), their amount sent is not significantly different from non-members (Table 6, column 1). When we consider members of all association types (All_Types_Out) we find that they send more than non-members, but only at a weak level of significance $(p=0.093)$. We conclude:

Result 1: Previous evidence support both the PUTNAM HYPOTHESIS A, according to which members of Putnam-type associations are expected to show higher level of generalized trust than non-members, and the OLSON HYPOTHESIS A, according to which members of Olson-type associations are not expected to be endowed with higher generalized trust than non-members. 
Second, we test for in-group favoritism for each of the association types. We start comparing the difference in the amount sent for in-group members and out-group members who belong to strictly one association type (Table 6, column 1). These three tests fail to reject the null hypothesis of equality of coefficients for all three association types, even though the level of significance for members of Olson-type associations is not far from $10 \%$ ( $p=0.673$ for Putnam-type; $p=0.252$ for Residual associations; $p=0.110$ for Olson-type associations). The failure to reject the null for the in-group effect may be caused by the regression coefficients being estimated with less precision due to the increased number of categories used to control for multiple membership in the out-group treatment. For this reason we run three further regressions where we introduce a dummy identifying all cases in which a subject is a member of at least one certain type of association. For instance, the dummy At_Least_One_Putnam-type_Out includes the four categories formed by: \{Putnam-type_Only_Out; Olson-type_\&_Putnam-type_Out; Putnam-type_\&_Residuals_Out; All_Types_Out\}. We also run analogous regressions using At_Least_One_Residual_Out (Table 6, column 3) and At_Least_One_Olson-type_Out (Table 6, column 4). Note that the previous result 1 holds when we use members of "at least one type of association" instead of strictly one type of association. When we consider members of at least one Olson-type association, the difference between sending directed to fellow members and sending towards the general population by people who are member of at least one Olsontype association is strongly significant $(p=0.006)$ (Table 6 , column 4). Members of at least one Residual association show in-group favoritism only at weak levels of significance $(p=0.063)$ (Table 6 , column 3$)$, but no effect emerges for Putnam-type associations $(p=0.850)$ (Table 6 , column 2$)$. We conclude:

Result 2: The comparison between behavior in the in-group and out-group treatments seems to support only the OLSON HYPOTHESIS B: members of Olson-type associations reveal higher levels of particularized trust than generalized trust. By contrast we find that members of Putnam-type associations do not.

With respect to the effect of socio-demographic controls on the amount sent, we find: a) a non-linear effect of the participant's age; b) that women send significantly less than men; c) that dissatisfaction with one's income has a negative effect on the amount sent; d) that people born in the South of Italy send less than people born in other areas; e) people who declare to believe in God, rather than being agnostic or atheists, send significantly less than others.

When we look at return rates across association types, we find that members of both Residual and Olsontype associations return significantly more than non-members, both when they are matched with fellow members (Residual_Ing $\mathrm{p}=0.001$ and Olson-type_Ing, $\mathrm{p}=0.022$, Table 6 , column 5), and when they interact with people from the general population (Residual_Only_Out $\mathrm{p}=0.044$ and Olson-type_Only_Out $\mathrm{p}=0.013$ Table 6, column 5). Perhaps surprisingly, Putnam-type association members are no more trustworthy than non-members, either in the in-group (Putnam-type_Ing, $\mathrm{p}=0.294$ ), or in the out-group treatment (Putnamtype_Only_Out, $\mathrm{p}=0.582$ ). The same results hold if we use members of "at least one type of association" instead of strictly one type of association.

Only Residual association members show some significant differences in behavior between the in-group and out-group treatment. This is the case both when members of strictly Residual associations are considered ( $p=0.088$ - Table 6 , column 5 ) and when members of at least one Residual associations are considered ( $p=0.021$ Table 6 , column 8). With respect to our third research question, namely, how members of different types of association behave when acting in response to a previous decision by another (trusting) subject, we conclude that: 
Result 3: Members of Residual and Olson-type associations result as more trustworthy than non-members both in the in-group and the out-group treatment, while Putnam-type association members' return rates are indistinguishable from non-members; in-group favouritism only emerges for Residual association members.

Among the controls, we find a non-linear effect of the amount received by the sender; that people born in the South and retired persons return significantly less; a negative effect of the number of family members. We also find a positive effect of the numbers of mistakes in the experiment comprehension test. ${ }^{10}$ We then explored possible differences in the effect of mistakes on the amount returned between the different association types. For this purpose we interact mistakes with each single dummy variable identifying the different association types (Table 6, column 6). Since the F-test on the null hypothesis that the coefficients of these interaction terms were jointly equal to 0 is not rejected $(p=0.6399)$, we conclude that no significant differences emerged in the way mistakes affect our dependent variable across groups of members.

\footnotetext{
${ }^{10}$ The Mistakes variable measures the number of mistakes in the 6-question comprehension quiz administered after the instructions. We preferred not to ask subjects to re-answer the questions in case of mistakes in the comprehension quiz, because we thought this would have conveyed the impression that subjects had "to pass an exam" to qualify for the experiment. This would have likely sounded unnatural and stressful for many subjects. We preferred to collect subjects' answers, and use the number of mistakes in the quizzes as a covariate in the econometric analysis.
} 
Table 6 - Analysis of amounts sent and return rates: effects of association type

\begin{tabular}{|c|c|c|c|c|c|c|c|c|}
\hline Dependent variable & $\begin{array}{c}\text { (1) } \\
\text { Amount sent }\end{array}$ & $\begin{array}{c}(2) \\
\text { Amount sent }\end{array}$ & $\begin{array}{c}\text { (3) } \\
\text { Amount sent }\end{array}$ & $\begin{array}{c}\text { (4) } \\
\text { Amount sent }\end{array}$ & $\begin{array}{c}\text { (5) } \\
\text { Return rate }\end{array}$ & $\begin{array}{c}\text { (6) } \\
\text { Return rate }\end{array}$ & $\begin{array}{c}\text { (7) } \\
\text { Return rate }\end{array}$ & $\begin{array}{c}\text { (8) } \\
\text { Return rate }\end{array}$ \\
\hline Model & Ordered Logit & Ordered Logit & Ordered Logit & Ordered Logit & Tobit & Tobit & Tobit & Tobit \\
\hline Putnam-type_Ing & $\begin{array}{c}1.041^{* * *} \\
(0.386)\end{array}$ & $\begin{array}{r}0.966^{* *} \\
(0.379)\end{array}$ & $\begin{array}{c}1.000 * * * \\
(0.381)\end{array}$ & $\begin{array}{c}1.027^{* * *} \\
(0.381)\end{array}$ & $\begin{array}{c}0.041 \\
(0.039)\end{array}$ & $\begin{array}{c}0.041 \\
(0.037)\end{array}$ & $\begin{array}{c}0.039 \\
(0.035)\end{array}$ & $\begin{array}{c}0.042 \\
(0.036)\end{array}$ \\
\hline Residual_Ing & $\begin{array}{c}1.754^{* * *} \\
(0.430)\end{array}$ & $\begin{array}{r}1.678^{* * *} \\
(0.426)\end{array}$ & $\begin{array}{c}1.668^{* * *} \\
(0.421)\end{array}$ & $\begin{array}{c}1.711^{* * *} \\
(0.426)\end{array}$ & $\begin{array}{c}0.172 * * * \\
(0.050)\end{array}$ & $\begin{array}{c}0.170^{* * *} \\
(0.048)\end{array}$ & $\begin{array}{c}0.168^{* * *} \\
(0.049)\end{array}$ & $\begin{array}{c}0.170 * * * \\
(0.047)\end{array}$ \\
\hline Olson-type_Ing & $\begin{array}{c}1.767^{* * *} \\
(0.488)\end{array}$ & $\begin{array}{r}1.826^{* * *} \\
(0.483)\end{array}$ & $\begin{array}{c}1.789 * * * \\
(0.486)\end{array}$ & $\begin{array}{c}1.746^{* * *} \\
(0.486)\end{array}$ & $\begin{array}{c}0.114^{* *} \\
(0.050)\end{array}$ & $\begin{array}{c}0.115^{* *} \\
(0.046)\end{array}$ & $\begin{array}{c}0.115^{* *} \\
(0.047)\end{array}$ & $\begin{array}{c}0.110 * * \\
(0.047)\end{array}$ \\
\hline Putnam-type_Only_Out & $\begin{array}{c}1.272 * * \\
(0.547)\end{array}$ & & $\begin{array}{c}1.248^{* *} \\
(0.536)\end{array}$ & $\begin{array}{l}1.287^{* *} \\
(0.541)\end{array}$ & $\begin{array}{c}0.029 \\
(0.053)\end{array}$ & & $\begin{array}{c}0.028 \\
(0.050)\end{array}$ & $\begin{array}{c}0.035 \\
(0.053)\end{array}$ \\
\hline Residual_Only_Out & $\begin{array}{c}1.202 * * \\
(0.468)\end{array}$ & $\begin{array}{r}1.151^{* *} \\
(0.462)\end{array}$ & & $\begin{array}{c}1.182 * * \\
(0.463)\end{array}$ & $\begin{array}{c}0.085^{* *} \\
(0.042)\end{array}$ & $\begin{array}{c}0.084 * * \\
(0.042)\end{array}$ & & $\begin{array}{c}0.084 * * \\
(0.042)\end{array}$ \\
\hline Olson-type_Only_Out & $\begin{array}{c}0.848 \\
(0.540)\end{array}$ & $\begin{array}{r}0.870 \\
(0.538)\end{array}$ & $\begin{array}{c}0.852 \\
(0.540)\end{array}$ & & $\begin{array}{c}(0.125)^{* *} \\
(0.050)\end{array}$ & $\begin{array}{c}0.124 * * \\
(0.049)\end{array}$ & $\begin{array}{c}0.124^{* * *} \\
(0.048)\end{array}$ & \\
\hline Putnam-type_\&_Olson-type_Out & $\begin{array}{l}-0.083 \\
(0.645)\end{array}$ & & $\begin{array}{l}-0.051 \\
(0.636)\end{array}$ & & $\begin{array}{c}0.038 \\
(0.049)\end{array}$ & & $\begin{array}{c}0.039 \\
(0.046)\end{array}$ & \\
\hline Putnam-type_\&_Residual_Out & $\begin{array}{c}1.186 * * \\
(0.469)\end{array}$ & & & $\begin{array}{l}1.174 * * \\
(0.461)\end{array}$ & $\begin{array}{c}0.081 * * \\
(0.039)\end{array}$ & & & $\begin{array}{c}0.084^{* *} \\
(0.038)\end{array}$ \\
\hline Olson-type_\&_Residual_Out & $\begin{array}{l}-0.035 \\
(0.622)\end{array}$ & $\begin{array}{l}-0.043 \\
0.618)\end{array}$ & & & $\begin{array}{c}0.017 \\
(0.056)\end{array}$ & $\begin{array}{c}0.018 \\
(0.055)\end{array}$ & & \\
\hline All_Types_Out & $\begin{array}{l}0.808^{*} \\
(0.481)\end{array}$ & & & & $\begin{array}{c}0.042 \\
(0.061)\end{array}$ & & & \\
\hline At_Least_One_Putnam-type_Out & & $\begin{array}{r}0.893^{* *} \\
(0.354)\end{array}$ & & & & $\begin{array}{c}0.050 \\
(0.032)\end{array}$ & & \\
\hline At_Least_One_Residual_Out & & & $\begin{array}{c}0.954 * * * \\
(0.343)\end{array}$ & & & & $\begin{array}{c}0.069 * * \\
(0.031)\end{array}$ & \\
\hline At_Least_One_Olson-type_Out & & & & $\begin{array}{c}0.496 \\
(0.374)\end{array}$ & & & & $\begin{array}{c}0.075^{* *} \\
(0.034)\end{array}$ \\
\hline Dropout & -0.228 & -0.225 & -0.230 & -0.230 & 0.000 & 0.000 & 0.000 & 0.000 \\
\hline
\end{tabular}




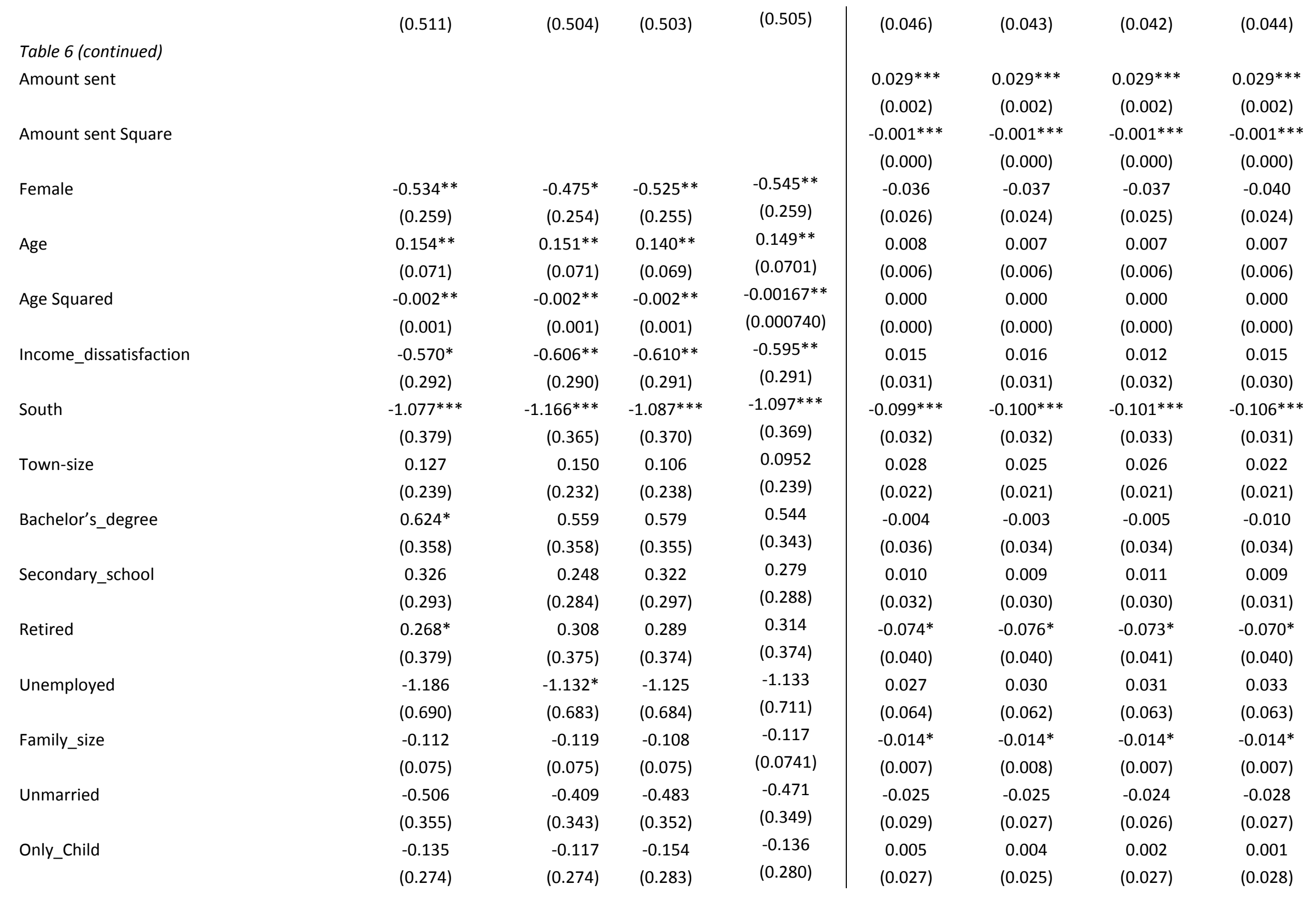




\begin{tabular}{|c|c|c|c|c|c|c|c|c|}
\hline Believer & $\begin{array}{c}-0.992^{* * *} \\
(0.333)\end{array}$ & $\begin{array}{r}-0.927 * * * \\
(0.328)\end{array}$ & $\begin{array}{c}-0.960 * * * \\
(0.327)\end{array}$ & $\begin{array}{c}-0.976 * * * \\
(0.331)\end{array}$ & $\begin{array}{l}-0.043 \\
(0.026)\end{array}$ & $\begin{array}{l}-0.041 \\
(0.025)\end{array}$ & $\begin{array}{l}-0.041 \\
(0.026)\end{array}$ & $\begin{array}{c}0.041 \\
(0.027)\end{array}$ \\
\hline \multicolumn{9}{|l|}{ Table 6 (continued) } \\
\hline \multirow[t]{2}{*}{ Practicing } & 0.348 & 0.386 & 0.398 & 0.347 & 0.037 & 0.040 & 0.039 & 0.034 \\
\hline & $(0.306)$ & $(0.307)$ & $(0.306)$ & $(0.301)$ & $(0.026)$ & $(0.025)$ & $(0.026)$ & $(0.027)$ \\
\hline \multirow[t]{2}{*}{ Divorced } & 0.033 & 0.012 & -0.040 & 0.0844 & -0.018 & -0.015 & -0.021 & -0.007 \\
\hline & $(0.611)$ & $(0.605)$ & $(0.572)$ & $(0.584)$ & $(0.090)$ & $(0.093)$ & $(0.090)$ & $(0.094)$ \\
\hline \multirow[t]{2}{*}{ Health_satisfaction } & 0.047 & 0.060 & 0.061 & 0.0662 & 0.020 & 0.020 & 0.021 & 0.021 \\
\hline & $(0.152)$ & $(0.153)$ & $(0.156)$ & $(0.153)$ & $(0.017)$ & $(0.017)$ & $(0.017)$ & $(0.017)$ \\
\hline \multirow[t]{2}{*}{ Risfin } & 0.084 & 0.087 & $0.087^{*}$ & $0.0878^{*}$ & -0.005 & -0.005 & -0.005 & -0.005 \\
\hline & $(0.052)$ & $(0.053)$ & $(0.052)$ & $(0.0527)$ & $(0.005)$ & $(0.005)$ & $(0.005)$ & $(0.006)$ \\
\hline \multirow[t]{2}{*}{ Mistakes } & -0.009 & -0.022 & -0.011 & -0.0151 & $0.018^{* *}$ & $0.017^{* *}$ & $0.017^{* *}$ & $0.017^{* *}$ \\
\hline & $(0.080)$ & $(0.077)$ & $(0.078)$ & $(0.0764)$ & $(0.008)$ & $(0.008)$ & $(0.008)$ & $(0.008)$ \\
\hline \multirow[t]{2}{*}{ Experimenter } & 0.375 & $0.400 *$ & $0.384^{*}$ & 0.371 & 0.032 & 0.031 & 0.033 & 0.032 \\
\hline & $(0.230)$ & $(0.229)$ & $(0.223)$ & $(0.229)$ & $(0.023)$ & $(0.022)$ & $(0.022)$ & $(0.022)$ \\
\hline \multirow[t]{2}{*}{ Other_Associations } & $-1.397^{*}$ & $-1.108^{*}$ & $-1.391^{* *}$ & $-1.429 * *$ & 0.004 & 0.003 & 0.003 & -0.006 \\
\hline & $(0.730)$ & $(0.643)$ & $(0.636)$ & $(0.697)$ & $(0.051)$ & $(0.050)$ & $(0.051)$ & $(0.053)$ \\
\hline \multirow[t]{2}{*}{ Constant } & Constants & Constants & Constants & Constants & -0.235 & -0.213 & -0.220 & -0.209 \\
\hline & omitted & omitted & omitted & omitted & $(0.161)$ & $(0.158)$ & $(0.150)$ & $(0.155)$ \\
\hline Observations & 319 & 319 & 319 & 319 & 1914 & 1914 & 1914 & 1914 \\
\hline Pseudo R2 & 0.0967 & 0.0930 & 0.0936 & 0.0940 & & & & \\
\hline sigma_u & & & & & 0.159 & 0.159 & 0.160 & 0.160 \\
\hline sigma_e & & & & & 0.148 & 0.148 & 0.148 & 0.148 \\
\hline chi2 & & & & & 431.8 & 438.1 & 458.6 & 424.9 \\
\hline
\end{tabular}

Notes: Putnam-type_Ing, Residual_Ing and Olson-type_Ing identifies subjects involved in the in-group treatment and recruited in Putnam-type, Residual and Olson-type associations respectively. Variables denoted by $X$ Only Out, $X=\{$ Putnam-type, Residual, Olson-type $\}$ identify subjects who are members of type of association $X$ in the out-group treatment. $X_{1} \&_{-} X_{2}$ Out, $X_{1}=X_{;} X_{2}=X$; identify subjects who, in the out-group treatment, are members of both association types $X_{1} \& X_{2}$, but are not member of the third association type, where $X_{1}$ and $X_{2}$ identify different types. For instance, Putnam-type_\&_Residual_Out identifies members who belong to at least one Putnam-type association, at least one Residual association, but are not members of Olson-type associations. All_Types_Out identifies subjects who are members of all three types of association in the outgroup treatment. Finally, At_Least_One_X_Out identifies subjects who are members of at least one association of type X. For instance, At_Least_One_Olson-type_Out includes the four categories: \{Olson-type_Only_Out; Olson-type_\&_Putnam-type_Out; Olson-type_\&_Residual_Out; All_Types_Out\}. Robust standard errors (columns 1,2,3, and 4) and bootstrapped standard errors generated in 1000 repetitions (columns 5,6,7, and 8) are reported in parentheses; ${ }^{* * *} p<0.01, * * p<0.05, * p<0.1$. See Appendix A for the description of the control variables included in the regressions. 
Finally, we analyze if the intensity of participation in different types of associations has an effect on trusting and trustworthy behavior of members. We consider the number of hours actually spent volunteering with associations and the number of associations joined by members. In both cases, we include in the regressions the dummy variables identifying membership in the different types of associations. Indeed, the coefficients of the variables measuring the intensity effect reveal the effect of the intensity net of the effect of the mere participation.

First we focus on the number of hours spent volunteering with associations of different types (defined as Hours). In regard with subjects involved in the in-group treatment, we considered the number of hours spent in the associations where they had been recruited. This was a natural choice, since these associations are those used to create the in-group condition (see section 3). With respect to subjects in the out-group condition, we restricted the analysis to members who belong strictly to one type of association. In fact, in case of members belonging to more than one association type, we are not able to impute the hours spent volunteering to the type of association where these have been spent ${ }^{11}$. The number of hours spent volunteering is never significant when we consider subjects in the in-group treatment belonging to the three different types of associations (Hours_Putnam-type_Ing, Hours_Residual_Ing, Hours_Olsontype_Ing) (Table 7, column 1). In the out-group treatment, the number of hours is not significant either for Putnam-type (Hours_ Putnam-type_Only_Out, $\mathrm{p}=0.103$ ) or for Residual associations (Hours Residual_Only_Out) ( $\mathrm{p}=0.420)$, but has a negative and significant effect for Olson-type associations (Hours_ Olson-type_Only_Out) ( $p=0.022$ ) (Table 7, column 1).

As for the relationship between Hours and members behavior when acting as Receiver, we do not detect any significant effect (Table 7, column 2).

A second analysis related to the intensity of the associational life, reveals that the number of associations joined by members (Number_Putnam-type_Out, Number_Residual_Out, Number_Olson-type_Out) does not affect the amounts sent (Table 8 , column 1 ).

As for return rates, we do not detect any significant effect of number of associations on trustworthiness in this case, either (Table 8, column 2).

In conclusion, we do not find evidence of a clear effect of intensity of participation on the level of trust and trustworthiness of members of different types of associations. We only find an effect of the intensity of participation in relation to the number of hours spent volunteering in associations, showing a negative effect of the number of hours spent volunteering on trust of members of Olson-type associations when they are paired with people from the general public.

\footnotetext{
${ }^{11}$ Asking the number of hours spent volunteering in each association would have of course been interesting, but the overall length of the questionnaire prevented us from doing that.
} 
Table 7 - Analysis of amounts sent and return rates: Effects of length of hours spent in association per week

\begin{tabular}{|c|c|c|}
\hline & $(1)$ & $(2)$ \\
\hline Dependent Variable & Amount sent & Return rate \\
\hline \multirow[t]{2}{*}{ Hours_Putnam-type_Ing } & 0.002 & 0.000 \\
\hline & $(0.005)$ & $(0.000)$ \\
\hline \multirow[t]{2}{*}{ Hours_Residual_Ing } & 0.001 & 0.000 \\
\hline & $(0.003)$ & $(0.001)$ \\
\hline \multirow[t]{2}{*}{ Hours_Olson-type_Ing } & -0.013 & 0.001 \\
\hline & $(0.009)$ & $(0.001)$ \\
\hline \multirow[t]{2}{*}{ Hours_Putnam-type_Out } & -0.296 & -0.007 \\
\hline & $(0.182)$ & $(0.039)$ \\
\hline \multirow[t]{2}{*}{ Hours_Residual_Out } & -0.068 & -0.006 \\
\hline & $(0.084)$ & $(0.006)$ \\
\hline \multirow[t]{2}{*}{ Hours_Olson-type_Out } & $-0.235 * *$ & 0.002 \\
\hline & $(0.102)$ & (0.019) \\
\hline \multirow[t]{2}{*}{ Putnam-type_Ing } & 1.139 & 0.004 \\
\hline & $(0.946)$ & $(0.083)$ \\
\hline \multirow[t]{2}{*}{ Residual_Ing } & $1.539 * * *$ & $0.174^{* * *}$ \\
\hline & $(0.547)$ & $(0.063)$ \\
\hline \multirow[t]{2}{*}{ Olson-type_Ing } & $2.599 * * *$ & -0.014 \\
\hline & $(0.631)$ & $(0.085)$ \\
\hline \multirow[t]{2}{*}{ Putnam-type_Only_Out } & 2.212 & 0.007 \\
\hline & $(1.473)$ & $(0.172)$ \\
\hline \multirow[t]{2}{*}{ Residual_Only_Out } & 1.258 & 0.071 \\
\hline & $(0.899)$ & $(0.057)$ \\
\hline \multirow[t]{2}{*}{ Olson-type_Only_Out } & $1.896 * * *$ & 0.107 \\
\hline & $(0.659)$ & $(0.065)$ \\
\hline \multirow[t]{2}{*}{ Dropout } & -0.426 & -0.033 \\
\hline & $(0.528)$ & $(0.041)$ \\
\hline \multirow[t]{2}{*}{ Amount sent } & & $0.030 * * *$ \\
\hline & & $(0.002)$ \\
\hline \multirow[t]{2}{*}{ Amount sent Square } & & $-0.001 * * *$ \\
\hline & & $(0.000)$ \\
\hline \multirow[t]{2}{*}{ Female } & $-0.722^{* *}$ & $-0.061 * *$ \\
\hline & $(0.320)$ & $(0.030)$ \\
\hline \multirow[t]{2}{*}{ Age } & 0.067 & 0.004 \\
\hline & $(0.092)$ & $(0.009)$ \\
\hline \multirow[t]{2}{*}{ Age Squared } & -0.001 & 0.000 \\
\hline & $(0.001)$ & $(0.000)$ \\
\hline \multirow[t]{2}{*}{ Income_dissatisfaction } & -0.323 & 0.019 \\
\hline & $(0.318)$ & $(0.040)$ \\
\hline \multirow[t]{2}{*}{ South } & $-1.109 * * *$ & $-0.131 * * *$ \\
\hline & $(0.404)$ & $(0.040)$ \\
\hline \multirow[t]{2}{*}{ Town-size } & -0.046 & 0.039 \\
\hline & $(0.274)$ & $(0.027)$ \\
\hline \multicolumn{3}{|l|}{ Table 7 (continued) } \\
\hline Bachelor's_degree & $1.119 * * *$ & 0.040 \\
\hline
\end{tabular}




\begin{tabular}{|c|c|c|}
\hline & $(0.407)$ & $(0.046)$ \\
\hline \multirow[t]{2}{*}{ Secondary_school } & 0.562 & 0.051 \\
\hline & $(0.369)$ & $(0.040)$ \\
\hline \multirow[t]{2}{*}{ Retired } & $0.048 * * *$ & $-0.126^{*}$ \\
\hline & $(0.534)$ & $(0.068)$ \\
\hline \multirow[t]{2}{*}{ Unemployed } & -2.166 & -0.048 \\
\hline & $(0.716)$ & $(0.075)$ \\
\hline \multirow[t]{2}{*}{ Family_size } & -0.139 & $-0.023^{*}$ \\
\hline & $(0.135)$ & $(0.012)$ \\
\hline \multirow[t]{2}{*}{ Unmarried } & -0.668 & -0.035 \\
\hline & $(0.444)$ & $(0.033)$ \\
\hline \multirow[t]{2}{*}{ Only_Child } & -0.057 & 0.035 \\
\hline & $(0.299)$ & $(0.034)$ \\
\hline \multirow[t]{2}{*}{ Believer } & $-1.439 * * *$ & $-0.070 * *$ \\
\hline & $(0.381)$ & $(0.032)$ \\
\hline \multirow[t]{2}{*}{ Practicing } & $0.884 * *$ & 0.031 \\
\hline & $(0.344)$ & $(0.034)$ \\
\hline \multirow[t]{2}{*}{ Divorced } & -0.397 & 0.009 \\
\hline & $(0.707)$ & $(0.113)$ \\
\hline \multirow[t]{2}{*}{ Health_satisfaction } & 0.254 & 0.022 \\
\hline & $(0.183)$ & $(0.021)$ \\
\hline \multirow[t]{2}{*}{ Risfin } & 0.079 & $-0.011 * *$ \\
\hline & $(0.062)$ & $(0.005)$ \\
\hline \multirow[t]{2}{*}{ Mistakes } & -0.009 & $0.023 * *$ \\
\hline & $(0.094)$ & $(0.010)$ \\
\hline \multirow[t]{2}{*}{ Experimenter } & 0.155 & 0.033 \\
\hline & $(0.270)$ & $(0.025)$ \\
\hline \multirow[t]{2}{*}{ Constant } & Constants & -0.108 \\
\hline & omitted & $(0.211)$ \\
\hline Observations & 232 & 1392 \\
\hline Pseudo R2 & 0.1299 & \\
\hline sigma_u & & 0.161 \\
\hline sigma_e & & 0.132 \\
\hline chi2 & & 411.2 \\
\hline
\end{tabular}

Notes: see Table 6. Variables whose name starts with "Hours" measure the number of hours per week spent volunteering in the type of association specified by the variable name. For example, Hours_Olson-type_Out measures the number of hours spent volunteering per week in Olson-type associations by members involved in the out-group treatment. Robust standard errors (column 1) and bootstrapped standard errors generated in 1000 repetitions (column 2) are reported in parentheses; ${ }^{* * *}$; *** $p<0.01, * * p<0.05, * p<0.1$. We omitted the variable Other_Associations because of problems of multi-collinearity. See Appendix A for the description of all the control variables included in the regressions. 
Table 8 - Analysis of amounts sent and return rates: Effects of number of joined associations

\begin{tabular}{|c|c|c|}
\hline Dependent variable: & $\begin{array}{c}\text { (1) } \\
\text { Amount sent }\end{array}$ & $\begin{array}{c}\text { (2) } \\
\text { Return rate }\end{array}$ \\
\hline Putnam-type_Ing & $\begin{array}{c}1.034 * * * \\
(0.387)\end{array}$ & $\begin{array}{c}0.039 \\
(0.037)\end{array}$ \\
\hline Residual_Ing & $\begin{array}{c}1.746 * * * \\
(0.431)\end{array}$ & $\begin{array}{c}0.169 * * * \\
(0.047)\end{array}$ \\
\hline Olson-type_Ing & $\begin{array}{c}1.778 * * * \\
(0.492)\end{array}$ & $\begin{array}{c}0.115^{* *} \\
(0.049)\end{array}$ \\
\hline Number_Putnam-type_Out & $\begin{array}{l}-0.099 \\
(0.465)\end{array}$ & $\begin{array}{l}-0.051 \\
(0.033)\end{array}$ \\
\hline Number_Residual_Out & $\begin{array}{c}0.145 \\
(0.160)\end{array}$ & $\begin{array}{c}0.023 \\
(0.021)\end{array}$ \\
\hline Number_Olson-type_Out & $\begin{array}{c}0.025 \\
(1.013)\end{array}$ & $\begin{array}{c}0.051 \\
(0.068)\end{array}$ \\
\hline Putnam-type_Only_Out & $\begin{array}{l}1.388^{*} \\
(0.814)\end{array}$ & $\begin{array}{c}0.090 \\
(0.069)\end{array}$ \\
\hline Residual_Only_Out & $\begin{array}{l}0.980 * \\
(0.591)\end{array}$ & $\begin{array}{c}0.051 \\
(0.053)\end{array}$ \\
\hline Olson-type_Only_Out & $\begin{array}{c}0.822 \\
(1.267)\end{array}$ & $\begin{array}{c}0.062 \\
(0.086)\end{array}$ \\
\hline Putnam-type_\&_Olson-type_Out & $\begin{array}{c}0.007 \\
(1.165)\end{array}$ & $\begin{array}{c}0.039 \\
(0.107)\end{array}$ \\
\hline Putnam-type_\&_Residual_Out & $\begin{array}{c}1.139 \\
(1.064)\end{array}$ & $\begin{array}{l}0.132 * \\
(0.074)\end{array}$ \\
\hline Olson-type_\&_Residual_Out & $\begin{array}{l}-0.236 \\
(1.490)\end{array}$ & $\begin{array}{l}-0.070 \\
(0.101)\end{array}$ \\
\hline All_Types_Out & $\begin{array}{c}0.726 \\
(1.524)\end{array}$ & $\begin{array}{c}0.039 \\
(0.127)\end{array}$ \\
\hline Dropout & $\begin{array}{l}-0.230 \\
(0.511)\end{array}$ & $\begin{array}{c}0.001 \\
(0.046)\end{array}$ \\
\hline Amount sent & & $\begin{array}{c}0.029 * * * \\
(0.002)\end{array}$ \\
\hline Amount sent Square & & $\begin{array}{c}-0.001 * * * \\
(0.000)\end{array}$ \\
\hline Female & $\begin{array}{c}-0.533^{* *} \\
(0.259)\end{array}$ & $\begin{array}{l}-0.038 \\
(0.025)\end{array}$ \\
\hline Age & $\begin{array}{c}0.152 * * \\
(0.072)\end{array}$ & $\begin{array}{c}0.008 \\
(0.006)\end{array}$ \\
\hline Age Squared & $\begin{array}{c}-0.002 * * \\
(0.001)\end{array}$ & $\begin{array}{c}0.000 \\
(0.000)\end{array}$ \\
\hline Income_dissatisfaction & $\begin{array}{c}-0.578 * * \\
(0.294)\end{array}$ & $\begin{array}{c}0.011 \\
(0.031)\end{array}$ \\
\hline South & $\begin{array}{c}-1.075^{* * *} \\
(0.381)\end{array}$ & $\begin{array}{c}-0.101 * * * \\
(0.032)\end{array}$ \\
\hline
\end{tabular}

Table 8 (continued) 


\begin{tabular}{|c|c|c|}
\hline \multirow[t]{2}{*}{ Town-size } & 0.126 & 0.028 \\
\hline & $(0.239)$ & $(0.021)$ \\
\hline \multirow[t]{2}{*}{ Bachelor's_degree } & $0.620^{*}$ & -0.008 \\
\hline & $(0.356)$ & $(0.034)$ \\
\hline \multirow[t]{2}{*}{ Secondary_school } & 0.327 & 0.010 \\
\hline & $(0.295)$ & $(0.030)$ \\
\hline \multirow[t]{2}{*}{ Retired } & 0.269 & -0.070 \\
\hline & $(0.388)$ & $(0.043)$ \\
\hline \multirow[t]{2}{*}{ Unemployed } & $-1.187^{*}$ & 0.033 \\
\hline & $(0.704)$ & $(0.062)$ \\
\hline \multirow[t]{2}{*}{ Family_size } & -0.112 & $-0.014^{*}$ \\
\hline & $(0.075)$ & $(0.008)$ \\
\hline \multirow[t]{2}{*}{ Unmarried } & -0.496 & -0.025 \\
\hline & $(0.363)$ & (0.027) \\
\hline \multirow[t]{2}{*}{ Only_Child } & -0.148 & 0.001 \\
\hline & $(0.275)$ & $(0.028)$ \\
\hline \multirow[t]{2}{*}{ Believer } & $-0.967 * * *$ & -0.036 \\
\hline & $(0.345)$ & $(0.027)$ \\
\hline \multirow[t]{2}{*}{ Practicing } & 0.348 & 0.039 \\
\hline & $(0.306)$ & $(0.026)$ \\
\hline \multirow[t]{2}{*}{ Divorced } & 0.047 & -0.010 \\
\hline & (0.619) & (0.089) \\
\hline \multirow[t]{2}{*}{ Health_satisfaction } & 0.042 & 0.019 \\
\hline & $(0.156)$ & $(0.017)$ \\
\hline \multirow[t]{2}{*}{ Risfin } & 0.085 & -0.005 \\
\hline & $(0.054)$ & (0.006) \\
\hline \multirow[t]{2}{*}{ Mistakes } & -0.012 & $0.017 * *$ \\
\hline & $(0.080)$ & $(0.008)$ \\
\hline \multirow[t]{2}{*}{ Experimenter } & 0.368 & 0.032 \\
\hline & $(0.231)$ & $(0.022)$ \\
\hline \multirow[t]{2}{*}{ Other_Associations } & $-1.396^{*}$ & -0.002 \\
\hline & $(0.767)$ & $(0.052)$ \\
\hline \multirow[t]{2}{*}{ Constant } & & -0.229 \\
\hline & & $(0.156)$ \\
\hline Observations & 319 & 1914 \\
\hline Pseudo R2 & 0.0971 & \\
\hline sigma_u & & 0.158 \\
\hline sigma_e & & 0.148 \\
\hline chi2 & & 475.5 \\
\hline
\end{tabular}

Notes: see Table 6. Variables whose name starts with "Number" measure the number of associations of the type specified by the variable name joined by the subject. For example, Number_Putnam-type_Out measures the number of Putnam-type associations joined by subjects involved in the out-group treatment. Robust standard errors (column 1) and bootstrapped standard errors generated in 1000 repetitions (column 2 ) are reported in parentheses; ${ }^{* *} p<0.01,{ }^{* *} p<0.05,{ }^{*} p<0.1$. See Appendix A for the description of the control variables included in the regressions. 


\section{Conclusions}

Putnam's hypothesis on the positive effect of associational participation on spirit of cooperation conflicts with Olson's hypothesis, which sees voluntary groups as pursuing private interests and setting up activities conducive to rent-seeking behavior. The existing empirical literature, based on survey data, provides only mixed evidence that is not conclusive on the Putnam vs. Olson debate. Moreover, the lack of experimental studies on this issue is particularly critical, since survey questions on trust and cooperative behavior are characterized by commonly recognized interpretative problems. By distinguishing between different types of associations, we provide the first experimental analysis on trust and trustworthiness of members of Putnam-type and Olson-type associations when paired with fellow members and with people from the general population and we compare members' behavior with that of non-members.

First, we find that members of Putnam-type associations trust people from the general public significantly more than non-members. Moreover, they do not discriminate between fellow members and people from the general population. The latter result opens interesting questions for further research revealing that direct and indirect reciprocity, reputation and sanctioning, which should have a specific effect on spirit of cooperation within associations, are not relevant when Putnam-type associations are considered. Second, members of Olson-type associations trust people from the general population in the same way as nonmembers do. Moreover, they trust fellow members more than people from the general population.

As far as receivers' behavior is concerned, we note that members of Olson-type associations return significantly more than non-members, both when they are paired with fellow Olson-type members, and when they are matched with people from the general public, and without in-group effect. Conversely, Putnam-type association members are no more trustworthy than people from the general population, either when they are paired with fellow members or when they interact with people from the general population. This is a particularly original and interesting result. It highlights that membership in different types of associations may be associated with patterns of behavior that vary significantly when different motivational drivers are analyzed. It also indirectly confirms previous evidence that different models must explain trust and trustworthiness (Johnson and Mislin, 2011; Sapienza et al., 2013).

We also show that the intensity of participation presents only a significant effect. In particular, we find a negative effect of the number of hours spent volunteering in the associations on trusting behavior of members of Olson-type association when paired with people from the general public. This is consistent with the idea that social relationships in Olson-type associations lead primarily to "bonding" rather than "bridging" social capital (Putnam, 2000).

Finally, we analyze behavior of members of Residual associations with respect to the Olson vs. Putnam distinction. As members of Putnam-type associations, these subjects trust people from the general public significantly more than non-members. However, as members of Olson-type association, they trust fellow members more than people from the general population. When acting as receivers, members of Residual associations behave as Olson-type members. No significant effect of the intensity of participation on members of Residual associations emerges.

Our contrasting evidence on the behavior of members of Putnam-type and Olson-type associations when acting as sender or receiver in a Trust Game experiment opens interesting questions for further research. How do members of different types of association behave when the context of interaction does not ask mainly for trust but for other types of motivational driver? In this perspective, it would be useful to replicate experimental analysis involving associational members in different games, such as Public Good Games, Ultimatum Game and Dictator Game. 


\section{APPENDIX A}

Table A1 - Variables description

\begin{tabular}{|c|c|}
\hline Age & Subject's age \\
\hline Female & Dummy Variable (DV) taking value one $(=1)$ if the respondent is a female \\
\hline Dropout & $D V=1$ if the respondent had been member of an association in the past \\
\hline Income_dissatisfaction & $\begin{array}{l}\mathrm{DV}=1 \text { if the answer to the questions "How well would you say that you are doing } \\
\text { financially these days?" is "Living in a comfortable way". Other possible answers: "Living } \\
\text { in an acceptable way"; "Barely getting by"; "It goes really badly" }\end{array}$ \\
\hline Town_size & $\mathrm{DV}=1$ if the town where the respondent lives has more than 100.000 inhabitants \\
\hline South & DV $=1$ if the respondent was born in the South of Italy \\
\hline Bachelor's_degree & DV $=1$ if the respondent has a university degree or higher title \\
\hline Secondary_school & $\begin{array}{l}\text { DV=1 if the respondent has attained high-school diploma ("Maturità" or "Licenza" in the } \\
\text { Italian education system) as their highest educational achievement. }\end{array}$ \\
\hline Retired & $D V=1$ if the respondent is retired \\
\hline Unenmployed & $D V=1$ if the respondent is unemployed \\
\hline Family_size & Number of family members \\
\hline Unmarried & $D V=1$ if the respondent is single \\
\hline Only_child & $D V=1$ if the respondent is an only child \\
\hline Believer & $D V=1$ if the respondent states $s /$ he is not atheist nor agnostic \\
\hline Practicing & $\begin{array}{l}\mathrm{DV}=1 \text { if the respondent is a church-goer, i.e. s/he attends religious services at least once } \\
\text { a month }\end{array}$ \\
\hline Divorced & $\mathrm{DV}=1$ if the respondent is divorced \\
\hline Health_satisfaction & $\mathrm{DV}=1$ if the respondent declares to be very satisfied with his/her health condition \\
\hline Risfin & $\begin{array}{l}\text { variable measuring the general willingness of the respondent in taking financial risk (it } \\
\text { takes integer values from } 1 \text { to } 10 \text { ). We used the measure of risk aversion based on a } \\
\text { question in the survey (Are you generally a person who is fully prepared to take risks or } \\
\text { do you try to avoid taking risks? Please tick a box on the scale, where the value } 0 \\
\text { means: 'unwilling to take risks' and 10: 'fully prepared to take risk'), which proved to be } \\
\text { a good measure of risk aversion (see Dohmen et al., 2011). }\end{array}$ \\
\hline Mistakes & Numbers of mistakes in the experiment comprehension test \\
\hline Experimenter & $\begin{array}{l}\text { dummy variable which distinguishes between the two experimenters who conducted all } \\
\text { the experimental sessions }\end{array}$ \\
\hline Other_Associations & $\begin{array}{l}11 \text { members were inadvertently recruited by Demoskopea, and classified as belonging } \\
\text { to "other associations" (see footnote 8). }\end{array}$ \\
\hline
\end{tabular}




\section{References}

Anderson, L.R., Mellor, J.M., \& Milyo, J. (2004), "Social Capital and Contributions in a Pubic-Goods Experiment", AEA Papers and Proceedings, 94: 373-376.

Andreoni, J. (1989), "Giving with Impure Altruism: Applications to Charity and Ricardian Equivalence", Journal of Political Economy, 97: 1447-58.

Andreoni, J. (1990), "Impure Altruism and Donations to Public Goods: A Theory of Warm-Glow Giving", Economic Journal, 100: 464-77.

Becchetti, L., \& Degli Antoni G. (2010), "The sources of happiness: Evidence from the investment game", Journal of Economic Psychology, 31(4): 498-509.

Bellemare, C., \& Kröger, S. (2007), "On representative social capital”, European Economic Review, 51(1): 183-202.

Berggren, N., \& Jordahl, H. (2006), "Free to trust: Economic freedom and social capital”, Kyklos, 59(2): 141169.

Bertrand M., \& Mullainathan, S. (2001), "Do People Mean What They Say? Implications for Subjective Survey Data", American Economic Review, 91(2): 67-72.

Brehm, J., \& Rahn, W. (1997). Individual-level evidence for the causes and consequences of social capital. American journal of political science, 41(3), 999-1023.

Charness, G. \& Rabin, M. (2002), "Understanding social preferences with simple tests", Quarterly Journal of Economics, 117: 817-869.

Cox, J.C. (2004), "How to identify trust and reciprocity", Games and Economic Behaviour, 46: 260-281.

Degli Antoni, G. \& Grimalda, G. (2013), "The value of real voluntary associations", Working Papers 2013/20, Economics Department, Universitat Jaume I.

Dohmen, T., Falk, A., Huffman, D., Sunde, U., Schupp, J. \& Wagner, G.G. (2011), "Individual risk attitudes: measurement, determinants and behavioural consequences", Journal of the European Economic Association, 9(3): 522-550.

Engelmann, D., \& Fischbacher, U. (2009), "Indirect reciprocity and strategic reputation building in an experimental helping game", Games and Economic Behavior, 67(2): 399-407.

Fehr, E., \& Gächter, S. (2000), "Fairness and Retaliation: The Economics of Reciprocity", Journal of Economic Perspectives, 14(3): 159-181.

Fehr, E., \& Schmidt, K.M. (1999), "A theory of fairness, competition and co-operation", Quarterly Journal of Economics, 114: 817-868.

Glaeser, E., Laibson, D., Scheinkman, J., \& Soutter, C. (2000), "Measuring trust", Quarterly Journal of Economics, 115: 811-846.

Knack, S. (2003), "Groups, Growth and Trust: Cross-Country Evidence on the Olson and Putnam Hypotheses", Public Choice, 117: 341-355.

Knack, S., \& Keefer, P. (1997), "Does Social capital have an economic payoff? A cross country investigation”, Quarterly Journal of Economics, 112(4): 1251-1287.

Johnson, N.D., \& Mislin, A.A. (2011), "Trust games: A meta-analysis", Journal of Economic Psychology, 32(5): 865-889.

Olson, M. (1965), The logic of collective action. Harvard University Press, Cambridge MA.

Olson, M. (1982), The rise and decline of nations. New Haven: Yale University Press. 
Paxton, P. (2007), "Association Memberships and Generalised Trust: A Multilevel Model Across 31 Countries", Social Forces, 86(1): 47-76.

Putnam, R.D. with Leonardi, R. \& Nanetti, R.Y. (1993), Making Democracy Work. Princeton: Princeton University Press.

Putnam, R.D. (2000), Bowling Alone: The Collapse and Revival of American Community. New York: Simon \& Schuster.

Sapienza, P., Toldra-Simats, A. \& Zingales, L. (2013), “Understanding Trust”, Economic Journal, 123: 10851390.

Seinen, I., \& Schram, A. (2006), "Social status and group norms: Indirect reciprocity in a repeated helping experiment", European Economic Review, 50(3): 581-602.

Stolle, D. (1998), "Bowling Together, Bowling Alone: The Development of Generalised Trust in Voluntary Associations", Political Psychology, 19(3): 497-525.

Stolle, D., \& Rochon, T.R. (1998), “Are All Associations Alike? Member Diversity, Associational Type, and the Creation of Social Capital", American Behavioral Scientist, 42(1): 47-65.

Tocqueville, A. (1840), De la démocratie en Amérique. English translation, Democracy in America. Chicago University Press, Chicago 2000.

Uslaner, E.M. (2002), The Moral Foundations of Trust. Cambridge: Cambridge University Press.

Wollebaek, D., \& Selle, P. (2002), "Does Participation in Voluntary Associations Contribute to Social Capital? The Impact of Intensity, Scope, and Type", Nonprofit and Voluntary Sector Quarterly, 31(1): 32-61.

Yamagishi, T., \& Yamagishi, M. (1994), "Trust and Commitment in the United States and Japan", Motivation and Emotion, 18(2): 129-66. 